\title{
MULTICULTURALISM IN EDUCATION INSTITUTION: STUDY ON MULTICULTURALISM PRACTICE IN WIJAYA KUSUMA ELEMENTARY SCHOOL IN LASEM REMBANG
}

\author{
Amirudin ${ }^{1}$, Mulyo Hadi Purnomo ${ }^{2}$ \\ Department of Anthropology, Faculty of Humanities, Diponegoro University Semarang, \\ Indonesia ${ }^{12}$ \\ Email:amdjtg@yahoo.com ${ }^{1}$, mulyohp@yahoo.com ${ }^{2}$
}

\begin{abstract}
Research is conducted to examine how multiculturalism is carried out in the field of educational with cultural approach. Through ethnographic methods, this study found that the multiculturalism practice in SD Wijayakusuma had happened, it can be seen by the dynamic interaction between inclusive actors. Elementary school students are openly abled to interact others without distinguishing ethnicity, religion, race and class. They have relation just the way they are, self openess, all students can be friends with anyone and express themselves without fear of threats from any parties. Based on the findings, the researcher suggested: schools must provide more inclusive service without discriminating between students, improving the student facilities needed, holding joint activity that entertain community to show mutual appreciation and respect people each other.
\end{abstract}

Keyword: Multiculturalism; Field of Educational; Learning Model

\section{Introduction}

Central Java has made education one of the development priorities as stated in the 2013-2018 Province Planning Document. Even with the latest policy that requires provinces to implement Sustainable Development Goals (SDGs) through Presidential Regulation No. 59 of 2017 concerning the Implementation of the Sustainable Development Goals, requiring the regions to design action plans to achieve educational goals. There are a number of indicators that must be fulfilled, including the Student Participation Rate (SPR).

From year to year, the numbers are still not overtaken if using national benchmarks. It can be seen from the targets set since 2013 - 2018 that the trend has not yet been reached. Recorded in 2013, the provincial government targeted the SPR at 98.83, but it only reached 98.60; 2014 targets 98.42, reached 98.32; and in 2015 set the number at 100 , but in fact only 98.43 was reached. That all must have a reason and the qualitative answers to the underlying causes are not yet available. This research is important to examine the factors that are the causes, especially if it is associated with the interest of students entering schools with cross ethnicities.

The relationship between Javanese and Chinese ethnicity is indeed an up and down trend from time to time. Especially if faced with political momentum. The practice of regional election at the Jakarta in April 2017 which gave birth to the thickening of indigenous-non-indigenous identity was very worrying, including in 
the education sector. There needs to be a reconstruction effort so that the contraction does not continue to drag on. Sociocultural transformation is needed towards the use of multiculturalism to closen up the indigenous-non-indigenous relations primarily in the education process.

The study of Javanese-Chinese ethnicity relations has indeed been done. Sumanto Al Qurtubi (2003: 231) for example has examined the flow of ChinaIslam-Java which shows the process of acculturation in the three socio-cultural ethnicities that have occurred. According to him, the Chinese Community has shown a big contribution in the process of historizing Islamization in Java in the 15th and 16th centuries originating from Canton, Chuang-Chou, Chang-Chou, Yunan, Swatow and other regions in South China which were the Islamic base in the beginning. They came to Java and other regions in Southeast Asia as traders, tourists, professional zending, and refugees. Likewise the research by Hoon (2012: 251) who examined "Race, Class, and Stereotyping in Indigenous Perceptions of Chineseness". His research has advantages because his study was able to uncover indigenous-nonindigenous interactions that show the relevance of "race", "class", "religion", and "education" in asserting ethnic differences and promoting ethnic barriers. Signs rooted in the barriers are still running in such a way that the signs limit hybridity.

The two studies, according to the researcher, contained weaknesses: First, the Al Qurtubi (2003) study focused more at the acculturation process of China-JavaIslam only from the perspective of socioreligious history and did not see how the acculturation of Chinese-Islamic-Javanese manifested in daily life days in the social realm of a society. Likewise, the study of Hoon (2012) which only focused on the essentialism perspective in cultural studies. His study was only focused on how the daily life practice in Javanese-Chinese relations was directed by emphasizing the distinctions of racial and stereotypical signs in everyday life. If so, then this study only strengthens an ethnic identity into something that is "taken for granted", passed down from generation to generation, without any opportunity for them to produces a new perspective of culture in a heterogeneous process of indigenous-non-indigenous relations in any sector.

Starting from Bourdieu's thought of "practice" in a "field" (2010, 1998), the researchers want to examine how culture as part of the cognition map is not only inherited from generation to generation that directs how humans act but also is produced and reproduced in a field. The relation of ethnicity in the field of education is assumed to be able to produce new cultural products that are multicultural which is produced through the process of production and reproduction in the education field.

By taking a research locus at an educational institution in Lasem known as "Small China" on the north coast of Java, this study examines how the practice of multiculturalism is carried out in educational institutions. And through it, the researchers construct the practice of multiculturalism that takes place in the relations of ethnicity in various fields that have been applied to the development of a multicultural-minded learning process.

\section{Research Methods}

Starting from the desire to examine and reveal closely how the practice of multiculturalism occurs in the education field involving actors (teachers, students, parents) from Javanese-Chinese ethnicity, this study took place at Wijaya Kusuma Elementary School whose students were very multi-identity from racial, ethnic, and religious sides. Through ethnographic methods, the researchers conducted fieldworks to find patterns of multiculturalism practices that had taken place at the research site by following the movements and activities of the actors 
(teachers and students) during the learning process at Wijaya Kusuma Elementary School.

The outcomes of this stage are ethnographic findings that describe various practices of multiculturalism in a number of areas that take place at the research site. In addition, the esearchers also tried to find and conclude the practice of multiculturalism as part of a cultural pattern resulting from the dynamic interaction of actors in the teachinglearning process in a multi-ethnic school environment. The output of this stage is an ethnographic description that illustrates how the practice of multiculturalism occurs in the process of dynamic interaction of multi-ethnic actors.

\section{Result and Discussion}

\section{a. The Overview of Wijaya Kusuma Elementary School}

Wijayakusuma Elementary School is located at Untung Suropati Street No. 74 Lasem Subdistrict, Rembang District. This school is the most favorite private school in Lasem Subdistrict with an A accreditation. Like other private schools, the school is managed by the Wijayakusuma Kindergarten/Elementary Foundation. The school building is decades years old which was founded around 1958. The school building is not like a school building in general because the building has the same character as Chinese houses. Looking from the front, the school building is exactly the same as an ancient Chinese house.

This school is located in a strategic place because it is located on the roadside of the northern coast(Pantura) of Java. While the distance between the school and the district is quite far, about $12 \mathrm{~km}$ from Rembang District, but it is still easily accessible because it is located on the
Pantura roadside. The location of the building is in the middle of the shops which are surrounded by ancient Chinese buildings.

Formerly this school was named Cuan Min Shue Shiau in 1958 which meant public school. Then in 1969, by the management of the foundation and the chairman of the foundation - Sigit Wicaksana - the name of the school was changed to Wijayakusuma. The reason for changing the name is because this school is not intended for Chinese only but also for schools of children from various tribes, ethnicities, and religions. The name Wijayakusuma itself has a meaning that symbolizes the lotus flower where the flower grows in dirty places but it still grows and blooms beautifully. The meaning has a great meaning that is illustrated by the atmosphere of the school, which can be shown in the fact that with the many public schools around Wijayakusuma Elementary School, but this elementary school still stands by holding its trademark. In this school, students are free to follow any religion they adhere to. Therefore, there are so many students with different religious attending this school.

Wijayakusuma Elementary School has a vision which is 'excellence in achievement, virtuous, intelligent, skilled, responsive, ready to be independent based on faith and piety'. The vision will be achieved through 4(four) missions: (a) Carrying out active, creative and fun learning and guidance processes so that students can develop according to their own potential; (b) Optimizing teacher potential in learning and skills activities; (c) Fostering appreciation and deepening the teachings that are embraced; (d) Optimizing cooperation with parents and the community to support.

Wijayakusuma Elementary School also has multicultural teachers. The majority are Moslem, and the rest are 
Catholics, Christians, and Hindus. Likewise with the students; of a total of 179 students in class $\mathrm{I}-\mathrm{V}$, there are 136 students $(75.97 \%)$ who are Muslim; 26 students $(14.52 \%)$ are Christians; 16 students $(8.94 \%)$ are Catholic; 1 student (0.56) is Hindu.

Wijayakusuma Elementary School has several facilities for extracurricular activities intended to improve the quality of the students according to the interests and talents of the students. Extracurricular activities are compulsory and some noncompulsory. The compulsory extracurricular is scouting, while the noncompulsory ones are dance and musical arts. This extracurricular activity is held once a week every Monday. This activity involves instructors from outside the school. There are special trainers who are invited from outside the school to teach dance. Same thing also happens with the extracurricular activity of the musical arts, it also invites teachers from outside the school.

In addition to extracurricular activities, this elementary school also has intracuricular activities such as prisma, flag ceremonies, morning gymnastic. Prisma activity is carried out on the scheduled school day, while morning gymnastic is carried out before entering the class in the morning with an arranged schedule. Flag ceremony is carried out like schools in general, ie routines every Monday. Besides Monday, it can also be done on certain days when there is a commemoration of national days.

Wijayakusuma Elementary School has facilities and infrastructure that are quite good in facilitating students in learning activities in schools, including teacher rooms, principal rooms, school's health center; Islamic, Christian, and Catholic subjects room; stationery store; library; administration room and extracurricular room.

b. Multiculturalism Practices in Wijaya Kusuma Elementary School
Multiculturalism occurs in a variety of areas. Based on close observations, there are 3 areas which are the core strengths of multiculturalism built in this school. The three areas are: (1) when students are in classroom arena; (2) the arena within the recess period; and (3) group learning arena. In each of the social arenas, students express their multiculturalism with unique patterns and varieties.

\section{i. Multiculturalism in the Classroom Arena}

Based on close observations while in the classroom, Wijayakusuma Elementary School's students interact closely, harmoniously without distinguishing their religion, ethnicity, and culture. The classroom atmosphere is conducive, and the learning runs smoothly. The teacher gives the lesson material well, students listen to what the teacher has to say. Sometimes when the learning process takes place, there are children joking around with other friends. This slightly interferes with the learning process because sometimes students who are joking also cause a fight between them, but it is not too difficult for the teacher to deal with the situation. The diverse character of students makes learning activities more interesting, as expressed by Yustina, The Head of Wijayakusuma Elementary School, saying that "there are many students here who are of different religions but can still get along without discriminating each other. All are harmonious and bond as kind friends. While in class they show a familiarity, joking around with each other and paying attention to the lessons regardless of their race and religion. "

That reality shows that they are associating "without barrier". They learn with fellow friends well and intimately. It is also shown from how they know each other. They joke with all their friends and listen to the lessons in an orderly manner, 
as revealed by Dewi as the fourth-grade teacher that said, "All this time it is seen that the association of the children with other friends are good, close with each other. Because I always emphasize to them to respect and respect each other, even though they are different in religion and culture but must remain harmonious because we are all the same as the citizens of Indonesia. I speak so not only during civic lessons but in each subject interspersed with such understanding."

The atmosphere of harmony in the classroom greatly helps creates multiculturalism. But that does not mean without obstacles. Sometimes there were a few quarrels among students, as stated by Widiyanti as class V teacher that said, "Usually the children get along well, close but sometimes there are also those who like to fight, they are kids anyway. Sometimes it is a problem of misunderstanding because of borrowing stationery, sometimes it is because they tease each other. But a fight between religious problems never happens."

Based on the observations of the researchers during the class, the pattern of association of students in the class was established in a good relationship even though they came from an atmosphere that was different in religion, culture, and ethnicity. But the differences were not an obstacle to keep recognizing each other, maintaining harmony and mutual respect for the differences that the students have. The pattern of association of the students who are close with one another without distinguishing religion, ethnicity and culture are able to create an inclusive class condition, where students do not close themselves. They have the right to get along with anyone and express themselves according to what they want.

\section{ii. Multiculturalism in the Arena Within Recess Period}

The potential for multiculturalism to be occured can also be seen in the arena within recess periods where students are freer in relation. Students can play with other people of different religions. Not only with the classmates but also with the junior and senior. During breaks, researchers saw an atmosphere of intimacy and harmony that was established between students. They played and joked around with each other and there was even an interesting phenomenon when the students mixed up while they were associating with each other. They played without distinguishing differences. This was revealed by Dewi as a fourth-grade teacher that "children, when they are resting ofcourse they would play together. They boys usually play football, while the girl sometimes eat snacks in their class, sometimes they play rubber jumping, sometimes they just talk in front of the class while joking with their friends."

They play while maintaining harmony between people. But that does not mean it runs smooth without conflict. At certain times sometimes, there is a fight in the playing atmosphere. This situation is as expressed by Yustina as the principle that siad, "all students play together, they are mixed together, without discriminating on religion. They respect each other between believers. What is clear is that someone who has been fighting all this time is still within reasonable limits. Sometimes they run and run and bump into their friends, teasing each other with their friends so that their friends feel offended."

The occurrence of quarrels is mostly happened between the male students. They tend to like playing something which nature uses physical strength such as when they play football in recess. That is in accordance with what was revealed by one of the fourth-grade students of Dodi that said, "In the recess period I usually play 
football with my friends who are Islam, Christians and Catholics. I've been fighting. Sometimes, they mock me then we often end up fighting. It happens usually when we play football with the five grade"

In contrast to the female students who in their breaks prefer to play something that does not use physical strength like jumping. Sometimes they are just joking around with friends in class or in front of their class. It was as expressed by Ayu as a five grade student that said, "If it is break time, I go to the canteen or in class. I play too but rarely do. If I do, usually I play bentengan with my friend"

Based on close observations, as well as statements from the teacher and students about the pattern of relations that occur during recess period, it can be concluded that students in the arena within recess period like to play just as how the other children who like to play. They play with friends who has both the same or different religion. The game they usually play is football, bentengan, rope jumping. When they are playing they do not discriminate between religion, culture, and ethnicity. So, the pattern of relations at the recess period is free for the students to play with anyone, hang out and interact with anyone thus create an inclusive atmosphere that students show by playing at recess with friends who are of different religions, ethnicities, and cultures.

\section{iii. Multiculturalism at the Group Learning Arena}

To create an atmosphere of multiculturalism in Wijayakusuma Elementary School, not only done in the classrooms arena and the arena within recess period but also takes place when they were in the group learning arena. In that arena also can be seen the extent to which intimacy is established and how interactions occur in a group with members who come from various religions, cultures, and tribes. Researchers saw that when they are in the arena of inner group learning, the female students discussed, they interacted with the group members. Not only that, sometimes from group members, one asked each other and joked with groups and with other members. This is as stated by Dewi as the fourth-grade teacher that said, "they are good at group learning, solid, work together, even though the children are different and I always appoint one of them in one group to be the leader of the group members. So that the children have a sense of responsibility to get the score together with that one group."

Group learning in the classroom will make students learn how to respect and appreciate different opinions from other group members. Moreover, in one group there are various students who have different backgrounds in terms of religion, culture, and ethnicity which can influence the course of the discussion going smoothly or not. This is in accordance with Widiyanti's statement as a five grade teacher that said, "if there is a difference in opinion with their friends during group discussion, I usually take the best answer from the answers from these children's answers. Sometimes voting can also be done. I always emphasize to the students to always respect and appreciate each other's answers."

Group learning also trains students to actively participate in questions or provide answers to the questions given by the teacher or provide answers that are different from other groups. In group learning, you will see how active or passive a student is in group work or in discussions and in group discussion. This is in accordance with the statement of a class IV student Yuvana that said, "I am active in the group study. Frequently ask questions too. Sometimes those from other groups are also asking. The point is, we all are asking questions to each other."

Based on the close observation, the researcher can draw conclusions that the students of Wijayakusuma Elementary 
School in group learning interact with each other well, work together solidly, actively but also some of them are still passive. But from the group learning activities, students do not discriminate between group friends who are of different religions, cultures, and tribes. They still interact closely.

So, the pattern of relations when they are learning in groups is that the groups are consisting of students of different groups of backgrounds ranging from religion, ethnicity, and culture. However, these differences do not become an obstacle for them to establish solid cooperation, so that the interaction of students with each other is equally open, which then creates an inclusive atmosphere in the classroom.

\section{iv. The Entity Supporting \\ Multiculturalism}

The study also found that there are a number of entities that support the creation of multiculturalism. A number of factors including factors of religion, ethnicity, culture, mutual respect and respect among others, and support from the community. At Wijayakusuma Elementary School there are different religions, but of course, there are also factor about majority and minority of the religion followers. At present, the dominating students are Muslims. But all of the school's treatment to all of its students is the same and equal. Eventhough there are a majority group, it does not make them to get a special treatment. The minority group also is not neglected. All the same, all balanced.

Tribal factors are also important in creating multiculturalism. There are Javanese and Chinese tribes in this school. The Lasem area is inhabited by people of different religions, tribes, and cultures. Starting from Java, China and part of the Lasem community also came from Madura, the Madurese. With the existence of different religions and tribes, there is potential for different cultures to emerge. Starting from Islamic culture or Chinese culture, they all have their own characteristics. Islamic culture is usually close with recitation, commemorating religious holidays such as the Maulud of the Prophet or Javanese people calls it as Muludan. Chinese culture usually has a culture of commemorating Christmas and Imlatan. They usually pray at their places of worship, namely in the church or in the temple by performing a lion dance or barongsai.

Of the three factors, mutual respect and appreciation are created between different people. Lasem people have blended with each other for years. There are no quarrels and conflicts between tribes or ethnics or religious groups. They do not close themselves to interact with each other, as well as Wijayakusuma Elementary School's students who are open to each other in interacting. Mutual respect can be shown by students in terms of tolerance, for example, Islamic students are praying so non-Islamic students must respect friends who are praying by not distrubing them. On the other hand, nonIslamic students are celebrating Christmas, so Islamic students are wishing Merry Christmas to students who are celebrating Christmas.

In addition to these four factors, there is still one that is not less important, namely the support of the surrounding community both from Lasem and from outside Lasem. This can be shown by the fact that there are still many people who send their children to school at Wijayakusuma Elementary School at Lasem. This school is indeed one of the most favorite schools in Lasem. Every year at the end of the year there is an art performance event, where the students showcase their cultural arts. This event invites the public to watch the art performance event. That way people can 
see how the mixing of religion, ethnicity and culture by the students who are so kind, harmonious, close and open to each other happening.

In addition to these supporting factors, there are still more significant supporting factors namely the change of the school name, free uniform Friday, teachers who have tolerance towards students, school rules that do not discriminate, meetings or discussions between the school parties and the parents of students, the mixing of cultural arts between Javanese and Chinese, the celebration of religious holidays, mutual assistance in the preparation of religious activities, and the enthusiasm of the people who are very enthusiastic about the school.

\section{v. The Obstacles in Realizing Multiculturalism}

\section{a. The Obstacle from Teacher's Inside Side}

In learning activities, of course, the teacher in educating the students has a number of obstacles faced both internally and externally. Teachers have internal obstacle that must be faced, especially students that are faced are those who have different backgrounds ranging from religion, ethnicity, and culture. Of course, they have different characteristics. Based on close observations, it is known that the internal obstacles faced by the teachers are how to understand the emotional level of students who are still unstable. This was shown in a learning activity in the classroom during the learning activities. There were students who deliberately teased the other friends who were paying attention to the lesson. Spontaneously, the teased friends reacted immediately with anger and a fight occurred. This is what the teacher must understand in facing such a situation. That each student has a different level of self-emotion, some are not easy to get angry when they are teased, some are easily get angry when they are teased.
Moreover, they are students from different backgrounds in terms of religion, ethnicity, and culture.

\section{b. The Obstacle from Teacher's Outside Side}

In addition to internal obstacles, there are also external obstacles faced by the teacher. One important obstacle is the influence from outside the school such as the influence of internet technology, association with friends and the television shows that are less educated. Students, when they are in school, are certainly different if they are outside of the school. We know that increasingly advanced technology has a negative impact on elementary school age children who still need supervision from all parties. The internet is very influential for them. Children are able to operate computers equipped with extensive networks, where they can see broad insights according to what they want. Frequently, they come to the internet cafe to see things that are not good like pornographic images. This is very bad for the development of children of the same age as elementary school students.

Then the next factor is peer interaction and association. Sometimes peers also influence the students behavior, such as dirty talk, smoking, and others. A number of television shows also influence children's development. Television programs that are less educational like kiss scenes were seen by children of their age will have a negative impact on their development. Everything they see and get from outside of the school will be brought into the classroom and can influence other friends such as talking dirty to their friends and telling them what they saw and got.

\section{c. Multiculturalism Practices in Educational Institutions}

Java is a tribe that has diversity. The diversity includes religion, culture, 
ethnicity, race, ethnicity, and between groups. All diversityies that is owned is very possible to emerge multiculturalism in a society, including elementary school education. Wijayakusuma Elementary School as one of the private primary schools has students with a diversity of religions, cultures, and tribes. This allows the realization of multiculturalism in a number of areas.

Based on research, Wijayakusuma Elementary School has an important role in realizing multiculturalism. The teachers as educators have a responsibility to provide students with an understanding of religious tolerance among students. The pattern of relationships that occur in the arena in the classroom shows that students with each other have dynamic kinship relationships. They are close to each other, joking not only with friends who are equal but also associating with friends of different faiths.

The grouping of multicultural communities in terms of their pattern of relations generally forms two types of society: exclusive and inclusive. Exclusive communities are people who feel afraid of other cultural influences that can damage their culture. That belief makes them limit their relationship with other communities. Whereas inclusive communities are people who are accommodative to other cultures so that they are easily connected with other communities and consider every human being to have the same dignity (Ata Ujan; 2009).

The results of the study show that the pattern of student relations that occurs in the arena in the classroom with the perspective of the theory of multicultural community grouping in terms of the attitude of the association is included in the continuous inclusive category. It can be seen from the pattern of student relations that occur in the arena in class, at the arena of recess periods, and at learning groups arena that create dynamic relationships between students do not discriminate between variations owned.

Based on the results of the study, there are supporting factors to create multiculturalism in Wijayakusuma Elementary School, including religious factors, cultural factors, support from the surrounding community, mutual respect and appreciation. In addition to a number of supporting factors, there are still more significant supporting factors namely the change of the school's name, free uniform Friday, Wijayakusuma Elementary School teachers who have tolerance towards the students, non-discriminatory school rules, meetings or discussions between school parties and the parents of the students, mixing cultural arts between Javanese and Chinese, Celebrating religious holidays, helping each other in preparing for their religious activities, as well as the enthusiasm of the people who are very enthusiastic about the school.

But these factors are motivated by a long history. It is no secret that our country is a country that has complete variation of spices, the strategic location of Indonesia and the Indonesian state which is divided into islands or archipelago that makes Indonesia have a pluralistic diversity between islands with one another and has their own differences. This situation attracted the attention of people from various countries to come to Indonesia. Those who came to Indonesia were not just looking for spices, doing research on Indonesian culture, or trading. However, some of them also began to settle in Indonesia and later sought marriage with Indonesian people.

With this fact, there is direct and indirect culture integration in Indonesia, between western and eastern cultures with Indonesian culture from each region visited. Lasem is indeed known as Small China by immigrants. This is because 
Lasem was a stopover for Chinese people. The presence of the Chinese people to Lasem is what makes the creation of religion in Lasem. This statement can be indicated by several houses in Lasem which are ancient Chinese buildings, many relics from the Chinese people in Lasem, and Chinese tombs.

Religious factors are one of the important supporting factors in creating multiculturalism at Wijayakusuma Elementary School in Lasem. Almost all types of religions that students have are in this school, although in each year the entire religion does not necessarily presence. Although the religion embraced by these students varies, each religion still teaches the importance of religious tolerance in the association.

In addition to religious factors, there are also cultural factors that support the creation of multiculturalism at Wijayakusuma Elementary School in Lasem. The culture at Wijayakusuma Elementary School in Lasem can be in the form of dance, music, and other traditional arts. The students who are Muslim, they generally have the art of Javanese dance and the art of Hadroh musical. Whereas the non-Islamic students, they generally have lion dance or barongsai.

But that does not mean that all the cultures that each student has cannot be done by other students. That is, students with different religions may play the culture art or maybe just want to know the culture. This is intended to bring interethnic cultural integration, such as the occurrence of a combination of Srikandi Mustaka Weni and Minakjinggo Dayun dances. This dance was played by students from Javanese and Chinese ethnic groups.

\section{Conclusion}

Based on the results of the discussion above, conclusions can be drawn. First, the practice of multiculturalism at Wijayakusuma Elementary School in Lasem has taken place and is seen from the dynamic interaction between actors who are very open and inclusive. Elementary students are openly able to interact with their friends without distinguishing their religion, ethnicity, and culture. They get along as they are, openly, not closing themselves, all students have the right to be friends with anyone and express themselves without fear of threats from any party in the school. The interactions that occur between students are intimate and harmonious, thus creating a sense of mutual respect and appreciation among each other.

Second, the factors that support the creation of multiculturalism include foundation's policy factors and managers who develop schools without dividers: religion, ethnicity, culture, and mutual respect and appreciation, and the community support for schools. In addition, the provision of infrastructure facilities for extracurricular activities that are cross ethnic; and there are still other significant supporting factors, namely the change of the school's name, free uniform Friday, The teachers who have a sense of tolerance towards the students, school rules that do not discriminate, meetings or discussions between school parties and the parents, mixing cultural arts between Java and Chinese, celebrating religious holidays, helping each other in preparing for religious activities, as well as the enthusiasm of the people who are very enthusiastic about the school.

Third, the obstacles faced by the teachers are more human nature such as in terms of learning, characteristics of students, and obstacles from outside the school. There are internal and external obsctacles. Internal obstacles faced by the teachers can be in the form of different characteristics of students who are emotionally unstable. External obstacle are in form such as the influence of technology, association with friends who are not good, and television programs that are less educating.

Overall, the pattern of diversity relations that happen at Wijayakusuma 
Elementary School is patterned on continuous inclusive state. Based on this conclusion, suggestions can be given, the school needs to continue to open up access space in each arena so that the practice of multiculturalism becomes more concrete and good. That even though they are different, they can still absorb each other and establish intercultural communication. That way, the outside community will put great trust and be willing to give full support to the activities held by the school.

\section{References}

Al Qurtubi, Sumanto. 2003. Arus CinaIslam-Jawa: Bongkar Sejarah atas Peranan Tionghoa dalam Penyebaran Agama Islam di Nusantara Abad XV \& XVI. Jakarta: LP3S dan Yayasan Nabil

Amirudin. 2018. Mengkongkritkan Multikulturalisme: Belajar dari Relasi Jawa - Cina di Lasem Rembang. Dalam "60 Tahun Antropologi Indonesia: Refleksi Kontribusi Antropologi untuk Indonesia." Jakarta: Pusat Kajian Antropologi, Departemen
Antropologi FISIP UI. Prosiding (ISBN-978-602-51002-1-5), p 419.

Amirudin. 2018. Antropologi Media: Agama dan Produksi Budaya di Layar Kaca. Semarang: Undip Press (ISBN-978-979-097-488-3

Amirudin. 2017. Film Tanda Tanya: Suatu Gagasan Merealisasikan Multikulturalisme. Nusa: Jurnal Ilmu Bahasa dan Sastra. Semarang: eISSN 0216-535X Vol. 12, No. 4. http://ejournal.undip.ac.id/index.php/ nusa/article/ view.

Ata Ujan, Andre dkk. 2009. Multikulturalisme: Belajar Hidup Bersama dalam Perbedaan. Jakarta: PT INDEKS

Bourdieu, Pierre. 1998. Practical on the Theory Reason of Action. California, Stanford: Stanford University Press.

Bourdieu, Pierre. 2010. Arena Produksi Kultural: Sebuah Kajian Sosiologi Budaya. Terjemahan Yudi Santosa. Yogyakarta: KreasiWacana.

Hoon, Chang-Yau. 2012. Identitas Tionghoa Pasca Suharto: Budaya, Politik, dan Media. Jakarta: Inspeal Ahimsakarya

Press 